\title{
10 år efter COP15: samfundsvidenskabelige perspektiver på bæredygtig udvikling
}

Rasmus Kehlet Berg, ph.d-studerende, Økonomisk Institut, Københavns Universitet; Anette Høite Hansen, ph.d.-studerende, Institut for Antropologi, Københavns Universitet; Ida Mangor, ph.d.-studerende, Afdeling for poedagogisk antropologi, Aarhus Universitet; Anne Bach Nielsen, ph.d.-studerende, Institut for Statskundskab, Københavns Universitet

I 2009 udgav Tidsskriftet Politik et temanummer om klimapolitik. Det var før det store internationale klimatopmøde, COP15, skulle afholdes i København, og netop klimapolitik var på manges læber. COP15 var en begivenhed, som rummede høje forventninger og håb for en international aftale, der skulle skabe en fælles bindende ramme for, hvordan nationalstaterne håndterer de klimaforandringer, som den naturvidenskabelige forskning så entydigt peger på. Forhandlingerne gik ikke som forventet, og slutresultatet - en politisk hensigtserklæring - blev af mange anset som utilfredsstillende. COP15 bekræftede således på mange måder, at samfundsvidenskaben har en vigtig rolle at spille for klimadagsordenen, og det blev tydeligt, hvordan mennesker ikke nødvendigvis tilpasser og integrerer den viden om klima, der er tilgængelig. Vores sociale systemer, institutioner og fællesskaber er komplekse, og der er derfor brug for forskning i samfund og socialt liv som en integreret del af klimaforskningen.

I december 2019 er det ti år siden, København var vært for COP15, og tiden er kommet til, at Politik atter gør status over den klimapolitiske dagsorden. Med udgangspunkt $\mathrm{i}$ forskellige dele af samfundsvidenskaben undersøger dette særnummer af tidsskriftet, hvordan vores samfund er gearet til at håndtere de konsekvenser, klimaforandringer medfører. Vi spørger, hvad der kan gøres anderledes og hvordan det gøres anderledes, og vi viser, at samfundsvidenskabelig forskning åbner op for forståelsen for og forandringen mod mere bæredygtige samfund. Igennem seks forskellige temaartikler, der inkluderer perspektiver fra medieforskning, historie, kommunikation, økonomi, antropologi og tværdisciplinære mobilitetsstudier, gør vi således status over den samfundsvidenskabelige klimaforskning i Danmark. Artiklerne giver dels et indblik i den udvikling, som dansk klimapolitik har gennemgået efter COP15 og peger på en lang række vigtige aktører både civile og statslige - der i dag arbejder med at få integreret en klima-, miljø-, og bæredygtighedsdagsorden. Samtidigt identificerer artiklerne en række værktøjer og opmærksomhedspunkter, som både begrænser og udvider potentialet for en mere grøn omstilling. Dette temanummer af Politik viser dermed, hvordan den samfundsvidenskabelige forskning ikke er begrænset til klimapolitik men i høj grad også fokuserer på de miljø- og 
bæredygtighedsmæssige problemstillinger, som også er blevet en del af den internationale dagsorden siden COP15. ${ }^{1}$

\section{Samfundsvidenskabernes tur}

Klimaforskningen startede på den naturvidenskabelige banehalvdel for at opnå eksakt viden om forandringer i klodens klima. Det altoverskyggende spørgsmål har i mange år været, hvorvidt klimaforandringerne er menneskeskabte, eller om de nærmere er et udtryk for naturlige svingninger. Den første 'epoke' i klimaforskningen har således handlet om at undersøge, hvilken indflydelse menneskelig aktivitet har på klimaforandringerne.

Den naturvidenskabelige forskning har længe været sikker i sin sag: Den fortsat stigende udledning af drivhusgasser resulterer i højere temperaturer med store konsekvenser til følge (IPCC 2014); herunder stigende vandstand, tørke, ekstreme vejrforhold, ændringer i økosystemer mv. Dette faktum har blandt andet ført til formuleringen af en ny videnskabelig geologisk betegnelse for den tidsalder vi befinder os i - den antropocane tidsalder (Steffen m.fl. 2018). Med begrebet hentydes til den tidsalder, hvor mennesket er blevet en geologiske virkende kraft på jorden. Begrebet om det antropocæne er stadig til debat, og bud på, hvornår den antropocæne tidsalder begyndte, spænder vidt, fra det første landbrug for 12.000-15.000 år siden og helt frem til produktions- og forbrugseksplosionen i 1960'erne (Chernilo, 2017, s. 48). Uanset hvordan begrebet 'det antropocæne' præcist afgrænses, står det klart, at de gensidige påvirkninger mellem mennesket og dets biofysiske omgivelser er fundamentale forudsætninger for indretningen af samfundet. Den næste epoke i klimaforskningen må derfor blive en epoke, hvor det undersøges, hvilke ændringer anerkendelsen af disse forudsætninger bør resultere i, men også hvordan ændringerne kan realiseres. Som Katherine Richardson, professor i biologisk oceanografi og medlem af Klimarådet, har udtalt om status for klimaforskningen: "Nu er det samfundsvidenskabernes tur".

De massive udfordringer forbundet til, hvordan de nødvendige ændringer kan realiseres, er blevet omtalt som et "super wicked problem" (Levin m.fl. 2007), blandt andet på grund af manglen på en central institution, der har mandat og tilstrækkelig gennemslagskraft til at gennemføre disse ændringer. Klimaforandringerne er som bekendt et grænseoverskridende problem, der fordrer samarbejde og problemløsning på tværs af landegrænser, som vi blandt andet ser i de interstatslige forhandlinger ved COP-møderne. Men kampen mod klimaforandringer og for bæredygtig omstilling har længe udspillet sig uden for statens domæne. Civilsamfundet startede ud i opposition til staten i 70'ernes miljøbevægelser, men op gennem 90'erne blev græsrodsaktivismen i højere grad professionaliseret via NGO'er (se fx Læssøe 2000 for en dansk kontekst). I det hele taget har

\footnotetext{
${ }^{1}$ I 2015 blev 17 mål for en bæredygtig udvikling frem mod år 2030 (i dansk tale 'Verdensmålene') vedtaget på et FN-topmøde, og så sent som i foråret 2019 satte en IPBES-rapport en tyk streg under det faktum, at også biodiversiteten er stærkt påvirket af klimaforandringer, og at et stort antal arter er truet som følge heraf (IPBES, 2019).
} 
såkaldt ikke-statslige aktører, som også tæller kommuner og private virksomheder, gennem de sidste 30 år spillet en stadig større rolle i arbejdet med at skabe bæredygtig omstilling både lokalt og globalt (Hoff et al. 2019, 1). Dette ser vi ikke mindst ift. den rolle, verdens storbyer påtager sig i disse år, senest ved C40-netværkets ${ }^{2}$ topmøde i København i oktober i år.

Hvordan, vi som mennesker og samfund agerer, har stor betydning for, hvordan vores biodiversitet, bæredygtige udvikling og (graden af) klimaforandringer vil se ud i fremtiden, ligesom vi har brug for samfundsvidenskaben til at undersøge, hvordan vi tilpasser os de forandringer, der er uundgåelige. Her anses teknologisk udvikling af mange som den gyldne løsning til at nå nationale og internationale klimamål. En sådan teknologi skal dog anvendes og tilpasses de mennesker og samfund, den placeres i (se fx Tjørring og Gausset 2016 for en analyse af, hvordan energirenoveringer i private boliger forstås og tilpasses af husejere). Også derfor er samfundsvidenskabelig forskning i miljø, biodiversitet, klima og bæredygtig udvikling vigtigt.

Tværfaglig indsats og samarbejde på danske universiteter

Kompleksiteten i studiet af både klimaforandringernes påvirkning og af de mangerettede mål om bæredygtighed, der diskuteres i både politiske og civile arenaer i disse år, kalder på et samarbejde på tværs af de human- og samfundsfaglige videnskaber. Et kald som de seneste år har materialiseret sig på flere danske universiteter. Herunder på det Samfundsvidenskabelige Fakultet under Københavns Universitet, hvor størstedelen af redaktørgruppen på dette temanummer er tilknyttet det nyligt oprettede 'Centre for Sustainability and Society', SUSY. Også blandt de studerende ser vi en tendens til at organisere sig på tværs af de klassiske discipliner. Det sker gennem større globale bevægelser som Fridays for Future, men også lokalt på de enkelte uddannelsesinstitutioner. På det Samfundsvidenskabelige Fakultet, Københavns Universitet, har studenterforeningen SIMA siden 2018 f.eks. samlet studerende med interesse for, hvordan samfundsvidenskaben bidrager til forbedring af klima og miljø. Samtidig mærker vi som undervisere, hvordan de studerende sætter stadig større krav til undervisning, der inkluderer bæredygtighedsaspekter.

Dette temanummer er endnu et eksempel på det øgede tværfaglige samarbejde, der finder sted på danske universiteter. Redaktørgruppen repræsenterer således fire forskellige samfundsvidenskabelige discipliner. Samtidig dækker artiklerne over en bred vifte af temaer, og reflekterer dermed, hvordan samfundsvidenskabens 'indtog' i klimaforskningen kan og skal repræsenteres fra mange forskellige disciplinære vinkler. På makroniveau viser temanummeret, at det er afgørende, hvordan det eksisterende økonomiske system, medielandskabet og politiske partier imødekommer og kommunikerer nuværende

\footnotetext{
${ }^{2}$ Netværk af store byer verden over, som arbejder for at styrke byers rolle og indsats i kampen mod klimaforandringer (se c40.org)
} 
og fremtidige klimaudfordringer. Vi starter således i det danske medielandskab med artiklen "Et tabt årti? Dansk klimadækning siden COP15", hvor Mikkel F. Eskjær afsøger tendenser i den danske klimadækning siden COP15-topmødet. Artiklen fremhæver mediernes rolle med at synliggøre klimaforandringer, som ellers i høj grad er abstrakte og usynlige. På baggrund af en kvantitativ indholdsanalyse vises det, at medierne har en aftagende interesse for klimaet efter COP15 topmødet i 2009. Artiklen argumenterer dog herefter for, at måden medierne skildrer klimaforandringerne på giver anledning til optimisme; Klimaskepticismen og hvad der opfattes som legitime kontroverser, altså hvad der reelt er til diskussion i klimadebatten, har rykket sig væsentligt.

Pernille Almlund fortsætter i artiklen "Konkrete udspil for ukonkrete udslip - politisk kommunikation om klima 2009 og 2019” med at kigge på, hvordan klimapolitik er kommunikeret til den danske befolkning. I denne artikel er fokus på udviklingen i den politiske kommunikation på Christiansborg. I en analyse af partiernes klimaudspil- og kommunikation viser hun, hvordan fokus har ændret sig fra at være på ressourcer og forholdet mellem afbødning og tilpasning i 2009 til i dag at handle om konkrete talværdier og beregninger, der gør de forskellige klimaudspil mere tilgængelige og centrale for partiernes politiske program. Et helt konkret og relevant eksempel på en sådan beregningsmodel til brug for klimapolitisk handling er et 'Grønt BNP'. I artiklen 'Hvordan kan miljø- og klimahensyn integreres i den økonomiske politik?" belyser et hold af forskere fra Københavns Universitet, DREAM-modelgruppen og Danmarks Statistik vigtigheden af at integrere klima- og miljøhensyn i den økonomiske planlægning i Danmark. Forskerne viser først hvordan det gennem et 'grønt BNP' kan blive belyst, hvorvidt økonomisk vækst sker på bekostning af miljøet. Dernæst argumenteres der for hvordan en 'Grøn Reform'-model kan vurdere hvordan den fremadrettede økonomiske udvikling kan forventes at påvirke miljø og klima, og hvordan udviklingen kan bringes i overensstemmelse med de politiske mål på disse områder.

Samtidig viser temanummeret, hvor vigtigt det er, at vi forsker i menneskers oplevelser og hverdag i den antropocæne tidsalder, og hvilke handlemuligheder, de benytter sig af enten privat, gennem deltagelse i grønne organisationer, eller som kommunale borgere. I artiklen "Den kommunale klimaindsats 1990-2018: en komparativ analyse af fem danske kommuners klimaindsats i et historisk perspektiv" fokuserer Mette Stidsen netop på klimainitiativer fra et kommunalt perspektiv. Med afsæt i fem danske kommuners klimaplaner konkluderer hun, at der er både store forskelle og ligheder i forhold til, hvordan kommunerne historisk sætter klima på den lokalpolitiske dagsorden. Artiklen giver således en indsigt $i$, hvordan kommunerne har udviklet deres klimaplaner igennem tiden. Her bliver det tydeligt, at lighederne særligt findes i afbødningsinitiativer, hvor der findes både internationale og nationale rammer, som kommunerne skal følge. Variationen er således størst i tilpasningsinitiativer, hvor kommunerne har større autonomi til at bestemme deres politik.

I temanummerets to sidste artikler zoomer vi endnu længere ind og kigger på de handlemuligheder, der findes for borgere i deres hverdagsliv. Nina Moesby Bennetsen tager fat i de dynamikker, der udspiller sig på mikroniveau og argumenterer for, hvordan 
netop hverdagsfortællinger kan bruges til at nuancere og berige forskningens forståelse af klimaforandringerne. Hvor det dominerende fokus på klimaforandringer, og hvad vi som samfund skal gøre ved dem, ofte kredser omkring spørgsmål om økonomi og teknologi, påpeges det i artiklen, hvordan hverdagsfortællinger kan belyse de sociale og kulturelle dimensioner af, hvad det vil sige at leve med klimaforandringer - og dermed være med til at pege på, hvor vi kan sætte ind for at skabe forandring.

Anette Høite Hansen kigger i artiklen "Et bofællesskab og en bevægelse" på forholdet mellem 'mikroaktivister' og 'makroaktivister' i danske økosamfund. 'Mikroaktivisterne' er dem der 'bare bor' og praktiserer en bæredygtig livsstil og omstilling gennem deres hverdagsliv, der udspiller sig i økosamfundenes klimavenlige bygninger og infrastruktur i fællesskaber med fokus på bl.a. selvforsyning og genbrug i dagligdagen. De såkaldte 'makroaktivister' bor også ofte selv i økosamfund, men udover at praktisere bæredygtighed i det daglige, engagerer de sig også i et eller flere af de nationale og internationale netværk, der advokerer for og arbejder med at udbrede kendskabet til økosamfund og bæredygtig livsstil mere generelt. Artiklen beskriver således, hvordan aktivisme på forskellige skalaer kommer til udtryk i danske økosamfund og i økosamfundsbevægelsen, og hvordan de har en gensidig betydning for den bæredygtig livsstil, der leves og repræsenteres.

De forskellige perspektiver præsenteret $\mathrm{i}$ dette særlige temanummer understreger vigtigheden $i$, at samfundsvidenskaben er bredt repræsenteret $i$ den fremtidige forskningsog, ikke mindst, undervisningsindsats på de danske vidensinstitutioner. Samfund og mennesker er komplekse, og det ændrer de forandringer vi står i - og overfor - ikke på. Tværtimod. Som vi har skitseret i denne indledning, er der momentum blandt både forskere og studerende inden for de samfundsvidenskabelige fag til at markere sig endnu stærkere på området. Samtidig har vi vist, at samarbejde og samtale blandt de forskellige discipliner er vigtigt, hvis indsatsen skal stå endnu stærkere. Med dette temanummer af Politik har vi taget et skridt i den retning, og vi vil fortsat gøre vores for at løbe med stafetten.

Litteratur

Chernilo, D. (2017). The question of the human in the Anthropocene debate. European Journal of Social Theory, årg. 20(1), s. 44-60. https://doi.org/10.1177/13684310 16651874

Gausset, T., Tjørring, L. (2016). Energy Renovation models in Private Households in Denmark. I: Gausset, Q., Hoff, J., red., Community governance and citizen driven initiatives in climate change mitigation. London, New York: Routledge, s. 89106. https://doi.org/10.4324/9781315700298-6

Hoff, J., Gausset, Q., Lex, S. (2019). Introduction. I: Hoff, J., Gausset, Q., Lex, S., red., The Role of Non-State Actors in the Green Transition: Building a Sustainable Future. London: Routledge, s.1-13. https://doi.org/10.4324/9780429280399 
IPBES (2019). Global Assessment Report on Biodiversity and Ecosystem Services. IPBES. Tilgængelig på: https://www.ipbes.net/global-assessment-report-biodiversity-ecosystem-services [Tilgået d. 15.11.19].

IPCC (2014). Climate Change 2014: Synthesis Report. Contribution of Working Groups I, II and III to the Fifth Assessment Report of the Intergovernmental Panel on Climate Change. Geneva, Switzerland: IPCC.

Levin, K., Cashore, B., Bernstein, S., \& Auld, G. (2007). Playing it forward: Path Dependency, Progressive Incrementalism, and the "Super Wicked" Problem of Global Climate Change. IOP Conference Series Earth and Environmental Science, årg. 6(50). https://doi.org/10.1088/1755-1307/6/0/502002

Læssøe, J. (2000). Eksperter eller bevægelse? Salt, årg. 9(6), s. 18-20.

Steffen, W. et al. (2018). Trajectories of the Earth System in the Anthropocene. PNAS (august 2018), årg. 115(33), s. 8252-8259. https://doi.org/10.1073/pnas. 1810141115 